\title{
A new genus and species of pigeon (Aves: Columbidae) from Henderson Island, Pitcairn Group
}

\author{
Trevor H. Worthy \\ Department of Earth and Environmental Sciences, University of Adelaide, Australia \\ trevor.worthy@adelaide.edu.au
}

\section{Graham M. Wragg}

Department of Zoology, Oxford University, United Kingdom

\section{Introduction}

An extensive fossil record of birds has now been described from many islands in the Pacific, as comprehensively reviewed by Steadman (2006a). In recurrent cases across the breadth of the Pacific, up to half the birds are extinct (Steadman 2006a) - for example, extinct-bird remains have been found in New Caledonia (Balouet and Olson 1989), Fiji (Worthy 2000, 2001), the Tongan and Cook Island groups (Steadman 1989a, 1993, 1995), Samoa (Steadman 1994), Niue (Steadman et al. 2000), Society Islands (Steadman 1989a), Marquesas (Steadman 1989a; Steadman and Rolett 1996), Hawaii (James and Olson 1991; Olson and James 1991), and Easter Island (Steadman 1995). Among the extinct taxa are many species of columbids (Balouet and Olson 1987, 1989; Steadman 1989a, 1989b, 1992, 1997, 2006a, 2006b; Worthy 2001; Worthy and Wragg 2003; Wragg and Worthy 2006).

Henderson Island of the Pitcairn Group is one of the most remote islands in Oceania (see Figure 1 in Wragg and Worthy 2006). It is located about $177 \mathrm{~km}$ east-northeast of the high volcanic island of Pitcairn, at $24^{\circ} 22^{\prime} \mathrm{S}, 128^{\circ} 18^{\prime} \mathrm{W}$. It is a relatively small raised atoll, with an area of about $37 \mathrm{~km}^{2}$, and is low, with a maximum elevation of $33 \mathrm{~m}$. Fossil birds were first recorded from Henderson Island by Steadman and Olson (1985), who studied 303 bird bones recovered from Sinoto's excavations (Fosberg et al. 1983; Sinoto 1983). These were dominated by sea birds, but among the few land birds, they reported two species of pigeon. They considered nine incomplete wing bones were inseparable from Ducula aurorae or D. pacifica, and two partial tibiotarsi and a mandibular fragment similar to Ducula galeata. This interpretation was challenged by Bourne and David (1986), who considered it more likely that these bones 
represented just one species with reduced wings. Despite examination of a further 2795 bird bones by Schubel and Steadman (1989), this issue was not resolved, although they did record the presence of a Gallicolumba species, based on a tarsometatarsus.

In 1991-1992, the large multidisciplinary Sir Peter Scott Commemorative Expedition to the Pitcairn Islands (Spencer and Benton 1995) included extensive archaeological and some palaeontological investigations (Weisler 1994, 1995; Wragg 1995a, b; Wragg and Weisler 1994). During these investigations, some 42 one metre square test pits were excavated in 11 archaeological and one natural site, resulting in a collection of some 42,213 bird bones (Wragg 1995a). Among four extinct land birds, Wragg and Weisler (1994) and Wragg (1995a) listed Columbidae n. gen et n. sp., Ducula n. sp., and Gallicolumba n. sp.. Steadman (1997, 2006a) continued to list Ducula aurorae and D. galeata from Henderson Island, while admitting that the taxonomy of the extinct columbids was unresolved. Subsequently, Worthy and Wragg (2003) have described G. leonpascoi, and Wragg and Worthy (2006) Ducula harrisoni. It is the purpose of the present contribution to describe the new genus and species Wragg and Weisler (1994) revealed.

\section{Methods}

Site terminology and excavation

The locations of the sites are shown in Weisler (1995:Figure 2) and Wragg (1995b:Figure 2.1) and we follow the site nomenclature used therein here and on specimen labels. During excavations, all sediment was sieved through $6.4 \mathrm{~mm}$ mesh sieves and selected samples fine-screened with 1.5 or $3.2 \mathrm{~mm}$ meshes (Wragg and Weisler 1994). Weisler initially sorted the bird bones from the recovered materials, and initial identification of these was made by Wragg (Wragg and Weisler 1994; Wragg 1995a, b). THW is responsible for the comparisons reported here.

\section{Abbreviations}

The following abbreviations are used in the text.

Institution: AIM, Auckland Institute and Museum, Auckland, New Zealand (NZ); AM, Australian Museum, Sydney, NSW, Australia; AMNH, American Museum of Natural History, New York, United States of America; BMNH, Natural History Museum, London, United Kingdom (formerly British Museum (Natural History)); CM, Canterbury Museum, Christchurch, NZ; FM, Fiji Museum, Suva, Fiji; LACM, Natural History Museum, Los Angeles County, California, USA; NMNZ, Museum of New Zealand Te Papa Tongarewa, Wellington (formerly National Museum of New Zealand, Dominion Museum, and Colonial Museum), NZ; MVZ, Museum of Vertebrate Zoology, University of California, Berkeley, California, USA; OM, Otago Museum, Dunedin, NZ; SAM, South Australia Museum, Adelaide, South Australia, Australia; USNM, United States National Museum, Smithsonian Institution, Washington D.C., USA; UWBM, Burke Museum, University of Washington, Seattle, Washington, USA.

Skeletal elements and descriptive terms used: Anatomical nomenclature for specific bone landmarks follows Baumel and Witmer (1993). Some common terms are abbreviated as follows: proc. for processus; artic. for articularis. Element abbreviations: cor, coracoid; cmc, carpometacarpus; phal. dig., digital phalanx; hum, humerus; pt, part; tib, tibiotarsus. The following abbreviations apply to single and plural usage of the elements. When listing material, bones are sometimes identified as left (L) or right $(\mathrm{R})$ elements. $\mathrm{L}$ or R prefixed by 'p' or 'd' indicates 'proximal' or 'distal' part of the element respectively, e.g. $\mathrm{dR}$ tib means the distal part of a right tibiotarsus. TP for test pit. 


\section{Measurements}

Measurements were made with Tesa ${ }^{\circledR}$ dial callipers and rounded to $0.1 \mathrm{~mm}$. TL: greatest length, except for the coracoid, which was measured down the medial side (ML). PW: proximal width in the lateromedial plane; DW: distal width.

\section{Comparative material}

All material is from modern skeletons unless stated otherwise. Extinct taxa are indicated $\dagger$.

Goura cristata (Pallas, 1764), western crowned pigeon, CM Av7110; SAM B.4997; SAM B.5057; SAM B.11546; SAM B.11551. Microgoura meeki (Rothschild, 1904), Choiseul pigeon $\dagger$, AMNH 24959, cast R tmt, cast dR tt from skin AMNH 616460, Choiseul Island, Solomon Islands. Didunculus strigirostris (Jardine, 1845), tooth-billed pigeon, CM Av7160, Samoa; AM O.303. Caloenas nicobarica (Linnaeus, 1758), Nicobar pigeon, NMNZ 22475; USNM 292221; USNM 557085; UWBM 38797; SAM B.5056; SAM B.36831; SAM B.51203. Otidiphaps nobilis (Gould, 1870), pheasant pigeon, USNM 614236. Gallicolumba stairi (G. R. Gray, 1856), friendly ground dove, BMNH S/1975.3.3. Fossil bones: NMNZ S38223, 54 bones 6 individuals, Vatulele Island, Fiji. G. rubescens (Vieillot, 1818), MVZ 46017. G. luzonica (Scopoli, 1786), MVZ 53804; LACM 89051; LACM 89050. G. rufigula (Pucheran, 1853), LACM 106368. G. criniger (Pucheran, 1853), LACM 89052. G. beccarii (Salvadori, 1876), AMNH 7718; USNM 615012; UWBM 43037. G. jobiensis (A. B. Meyer, 1875), AM O.64814; AMNH 6753. Columba vitiensis (Quoy and Gaimard, 1830), white-throated pigeon, AM O.7921; FM 26. Columba leucomela (Temminck, 1821), white-headed pigeon, SAM B.31352; AM O.58907. Columba livia (Gmelin, 1789), rock pigeon, SAM B.46041; SAM B.46044; SAM B.46046. Streptopelia chinensis (Scopoli, 1786), spotted dove, AIM B5632; SAM B.48177; SAM B.49668. Phaps chalcoptera (Latham, 1790), common bronzewing, CM Av7129; SAM B.46373; SAM B.48297. Phaps elegans, (Temminck, 1810), brush bronzewing, SAM B.37405; SAM B.47648. Ocyphaps lophotes (Temminck, 1882), crested pigeon, SAM B.48075; SAM B.48078. Chalcophaps indica (Linnaeus, 1758), emerald dove, SAM B.31777; SAM B.37059; SAM B.38758. Macropygia phasianella (Temminck, 1821), large brown cuckoo dove, SAM B.38504; SAM B.38757. Leucosarcia melanoleuca (Latham, 1801), Wonga pigeon, SAM B.5090; SAM B.10598. Ptilinopus perousii (Peale, 1848), many-coloured fruit dove, FM 31; FM23. Ptilinopus victor (Gould, 1871), orange dove, FM unreg.; BMNH S/1975.3.1. Ptilinopus porphyraceus (Temminck, 1821), crimson-coloured fruit dove, NMNZ 16391. Ptilinopus magnificus (Temminck, 1821), magnificent fruit dove, SAM B.21929; SAM B.46569. Ptilinopus regina (Swainson, 1825), pink-capped fruit dove, SAM B.37060. Ducula goliath (G. R. Gray, 1859), New Caledonian imperial pigeon, NMNZ 22839, 3 mixed individuals. Ducula pacifica (Gmelin, 1789), Pacific pigeon, AM O.7919; NMNZ 16389A; NMNZ 25350; NMNZ 25351; NMNZ 25352; NMNZ 25353; AIM 7233; AIM 7262. Ducula latrans (Peale, 1848), Peale's imperial pigeon, FM 28; BMNH S/1975.3.4; BMNH S/1975.3.2; MVZ 51372. Ducula galeata (Bonaparte, 1855), Marquesan imperial pigeon, BMNH S/1975.9.5; NMNZ 26971, cast of selected elements BMNH S/1975.9.5. Ducula bicolor (Scopoli, 1786), pied imperial pigeon, AM O.68476. Ducula melanochroa (Sclater, 1878), Bismarck imperial pigeon, USNM 615013. Ducula pistrinaria (Bonaparte, 1854), island imperial pigeon. D. pistrinaria pistrinaria, UWBM 60203. Ducula rubricera (Bonaparte, 1854), red-knobbed imperial pigeon. D. rubricera rufigula, UWBM 63088. Ducula spilorrhoa (G.R. Gray, 1858), Australian pied imperial pigeon, SAM B.23902. Hemiphaga novaeseelandiae (Gmelin, 1789), New Zealand pigeon, OM Av1851, many NMNZ specimens. 
Fossil specimens compared: Gallicolumba leonpascoi- NMNZ specimens listed in Worthy and Wragg (2003), but especially coracoids S.40776, R; S.40804, pR; S.40831, L; carpometacarpi S.40786, L; S.40816, R; S.40828, R; and humeri S.40793, dR; S.40796, pR; S.40826, R; S.40828, L; S.40833, 2L; S.40843, 1L1dL. S.40847, R; and tibiotarsus S.40842, dL.

Ducula harrisoni - NMNZ specimens listed in Wragg and Worthy (2006), but especially coracoids S.41618, R, S.41639, L; S.41640, R; S.41728, R; S.41758, L; tibiotarsi S.41717, 1sL2dR; humeri S.41641, 2pL; S.41649, dR; S.41722, dL; carpometacarpi S.41617, L; S.41684, R; and S.41760, sternum.

\section{Systematic palaeontology}

Class Aves

Order Columbiformes

Family Columbidae

The fossils described here are referred to Columbidae as they have the following combination of characters. Coracoid elongate; cotyla scapularis (scapular cotyla) flat, not forming deep cuplike depression; proc. acrocoracoideus (acrocoracoid) large, overhangs medial margin of shaft; proc. procoracoideus (procoracoid) lacks foramen; impressio m. sternocoracoidei (sternocoracoidal impression) contains at least one area of pneumatic foramina. Humerus: caudo-cranially inflated; crista deltopectoralis (deltoid crest) short, robust, triangular; tub. dorsale (dorsal tubercle) elongate, merges into caput humeri (head) medially; head markedly convex proximally; fossa pneumotricipitalis ventralis (ventral pneumotricipital fossa) large, pneumatic; no dorsal pneumotricipital fossa; and no impressio coracobrachialis (bicipital furrow).

\section{Bountyphaps new genus}

Type species. Bountyphaps obsoleta nov. gen. et sp.

Etymology. For both the ship Bounty on which Europeans discovered the Pitcairn Group, and for the former bounty this bird provided re food; and 'phaps' Greek, feminine noun for wild pigeon.

Diagnosis. A genus of pigeon slightly larger than Ducula latrans characterised by the following unique combination of coracoidal characters: 1 , large pneumatic foramina penetrating acrocoracoid from supracoracoidal sulcus; 2 , sternocoracoidal impression separated from medial margin by broad ridge, pneumatic foramina located centromedially; 3 , tip of procoracoid not extending as lobe craniad of scapular cotyla; 4, facies artic. clavicularis (clavicle facet) notched, distinct ventral and dorsal lobes; 5 , ventral lobe of clavicle facet hooked sternally; 6, base of procoracoid short relative to shaft length; 7, deep depression at distal end humeral articular facet on lateral facies of shaft.

\section{Comparisons}

Compared especially to Pacific pigeon genera, Bountyphaps is larger than any species of Phaps, Chalcophaps, Ocyphaps, Macropygia, Ptilinopus (with single exception of P. magnificus of Australia), Drepanoptila, Gallicolumba and Didunculus. It is similar in size to larger species of Columba and Ducula, although smaller than Ducula galeata and D. goliath. It is markedly smaller than Natunaornis, Goura and Caloenas, but perhaps not much smaller than Microgoura. The diagnostic characters, whose distributions within columbid genera are given in Table 1, differentiate Bountyphaps from other genera as follows. Presence of a large pneumatic foramen under the acrocoracoid is only found in Ptilinopus, Macropygia, Goura, Caloenas (variably present e.g. 
A new genus and species of pigeon (Aves: Columbidae) from Henderson Island, Pitcairn Group 503

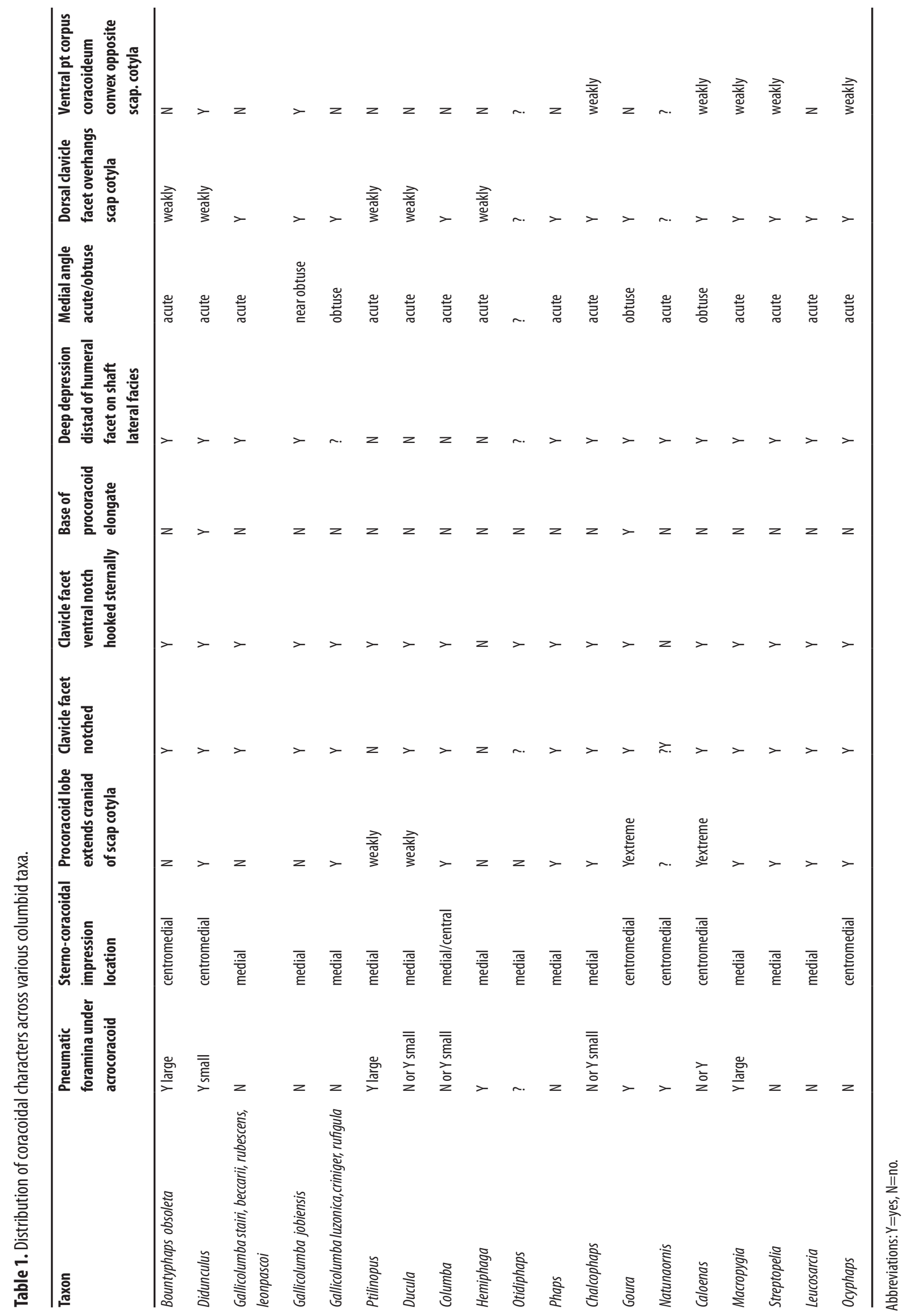


USNM 292221 is pneumatic, and USNM 557085 is not), and Natunaornis. In all other genera, either pneumatic foramina are absent, e.g. Phaps, Gallicolumba, or may be present or absent, but if present are very small (e.g. Didunculus, Ducula, Hemiphaga, Columba, Chalcophaps). The region of pneumatic foramina in the sternocoracoidal impression is located towards the centre of the bone similar to Goura, Caloenas, Natunaornis and Didunculus, thereby differing from Ducula, Hemiphaga, Columba, Ptilinopus, Macropygia and Gallicolumba in which it is medially located. In Otidiphaps coracoids, the sternocoracoidal impression is relatively much larger and deeper, even more so than in Goura and Caloenas, and it is pneumatic medially, rather than centrally. That the tip of the procoracoid does not extend as a lobe above the scapular cotyla towards clavicle facet differs greatly from Goura and Caloenas, where there is extreme cranial development of the procoracoid tip to nearly reach the clavicle facet and does enclose a canal through the supracoracoidal sulcus. Many other genera, including Didunculus, have significant extension of the procoracoid towards the acrocoracoid (Table 1). This character is variable in Gallicolumba, as in taxa from Oceania the procoracoid is relatively small and does not extend craniad of the scapular cotyla, but in taxa from the western Pacific, e.g. G. luzonica, G. criniger and $G$. rufigula, the procoracoid is relatively enlarged cranially. A notched clavicle facet further distinguishes Bountyphaps from Ptilinopus, which lacks such a notch. A sternally hooked ventral lobe of the clavicle facet distinguishes Bountyphaps from Natunaornis and Hemiphaga, where such a hook is absent. A short base to the procoracoid distinguishes Bountyphaps from Goura, where the juncture with the shaft is very elongate, comprising about 30 percent of length from the scapular cotyla to the medial angle, and to a lesser extent from Didunculus (24 percent) and Caloenas (c. 15 percent). The fossil has a distinct elongate fossa immediately distad of the humeral facet on the lateral facies. This feature, noted by Steadman (2006b), is shared with the Pacific columbids Didunculus, Gallicolumba, Goura and Caloenas, thus differentiating it from other Pacific columbids including Ptilinopus, Ducula and Columba. Steadman (2006) noted that a convex humero-ventral portion of the corpus coracoideum, which we interpret as the ventral facies adjacent to the humeral facet and opposite the scapular cotyla, was a feature of Didunculus. We found this feature difficult to interpret in smaller taxa, but in most pigeon genera the shaft is flattened in this area. In NMNZ S.44246, it is flattened, unlike Didunculus, Gallicolumba jobiensis and Caloenas.

In Bountyphaps, the sternocoracoidal impression is bound medially by a ridge that is not closer than $2 \mathrm{~mm}$ from the medial edge, diverges from the medial margin cranially, and extends nearly to mid-length, where it is centred on the dorsal facies. In Didunculus and Ducula, this ridge tends to converge on the medial margin cranially, but in Columba and Gallicolumba remains separated from it. The angulus medialis is acute with the profile of the medial margin evenly concave towards the tip in Bountyphaps (as in Gallicolumba stairi), rather than convex in profile towards the tip as is characteristic of Didunculus, Ptilinopus and Columba, but also some Gallicolumba e.g. G. jobiensis. It lacks a flange-like ridge leading proximally along the margin from the medial angle, which when present creates a convex profile of the medial margin above the angle, e.g. as in Ptilinopus, Columba and Didunculus. The sternal articulation has large dorsal and ventral facets. The profile of the sternal margin is shallowly concave, not markedly concave, as Ducula species.

In summary, Bountyphaps has more features in common with Didunculus than other taxa, yet it differs considerably as follows: procoracoid with shorter base and tip not hooked cranially, larger pneumatic foramina in supracoracoidal sulcus, sternocoracoidal impression more widely separated from the medial margin, and the medial angle is more acute and lacks a convex medial margin. 


\section{Bountyphaps obsoleta nov. gen. et sp. (Figures 1 and 2)}

Holotype. NMNZ S.44246, R coracoid, near complete, but part of the mid-shaft region ventrally, the tip of the proc. lateralis (lateral angle), and the extreme tip of the procoracoid are lost.

Etymology. Latin, feminine, adjective for extinct or forgotten about.

Diagnosis. As for genus.

Measurements of the holotype.

Medial length $42.7 \mathrm{~mm}$, least shaft width $3.8 \mathrm{~mm}$, length scapular cotyla to tip of acrocoracoid $14.3 \mathrm{~mm}$, length scapular cotyla to cranial end of humeral facet $9.6 \mathrm{~mm}$.

Type Locality. Henderson Island, site 5, test pit 10, spit 6; collected by M. Weisler and G. Wragg during the Pitcairn Islands Scientific Expedition 1991-1992.

Paratypes. All from Henderson Island and collected by M. Weisler and G. Wragg during the Pitcairn Islands Scientific Expedition 1991-1992. NMNZ S.44256, dR tib, site 5, unit 6, spit 2; S.44247, pL hum, site 5, unit 15, spit 4; S.44244, L cmc, site 5, unit 2, spit 12; S.44259, dL tib, site 5 , unit 8 , spit 3 .

Referred Material. All from Henderson Island and collected by M. Weisler and G. Wragg during the Pitcairn Islands Scientific Expedition 1991-1992. NMNZ S.41737, dR hum, site 5, unit 16, spit 3; S.41753, dL hum, site 5, unit 16, spit 50; S.44242, R phal. dig. major (prox.), site 1, unit 2, spit 1; S.44243, R phal. dig. major (prox.), site 5, unit 7, spit 2; S.44245, sternal pt R coracoid, site 5, unit 7, spit 1; S.44248, L metatarsal, site 5, unit 5, spit 3; S.44249, L metatarsal, site 11, unit 5, spit 4; S.44250, L scap, site 5, unit 5, spit 4; S.44251, L scap, site 5, unit 7, spit 2; S.44252, L scap, site 6, unit 3, spit 3; S.44253, anterior sternum, site 5, unit 8, spit 3; S.44257, sL tib, site 5, unit 8, spit 3; S.44258, pR ulna, site 5, unit 1, spit 14.

All these specimens are referred to Bountyphaps obsoleta, as they are pigeon bones, but are not Ducula harrisoni nor Gallicolumba leonpascoi, and are too large to be referred to Ptilinopus insularis.

In addition to the characters discussed under the generic diagnosis, the coracoid has the following features (Figure 1). The dorsal lobe of the clavicle facet is expanded dorsally so that medially it overhangs the scapular cotyla, however this is accentuated by an apparent pathology on the dorsal side of this facet. The shaft in dorsal view widens caudally, that is, lacks a section with parallel sides, as in for example Gallicolumba. The ventral margin of the facies artic. humeralis extends ventrally as a prominent ridge over the shaft ventro-laterally.

Bountyphaps obsoleta is easily distinguished from coracoids of other columbids on Henderson Island. It is markedly larger than those of Ptilinopus insularis and Gallicolumba leonpascoi. While of similar size to those of Ducula harrisoni (Table 2), it is distinguished by a relatively more robust cranial end, the presence of pneumatic foramina in the supracoracoidal sulcus and a centromedially placed sternocoracoidal impression. In D. harrisoni, the impression is deepest and pneumatic closest to the medial margin and its defining ridge medially is narrowly separated from and converges on the medial margin cranially.

Humerus. The pL humerus S.44247 (Figure 2) is of typical columbid form, but is distinguished from all genera except Didunculus, Goura, Caloenas and Gallicolumba by the presence of a marked tuberosity located caudally on the distal margin of the caput at the end of the capital groove and above the pneumotricipital fossa. It is smaller than specimens attributed to Ducula harrisoni (Table 2).

Carpometacarpus. The L carpometacarpus NMNZ S.44244 (Figure 2), length $33.8 \mathrm{~mm}$, 


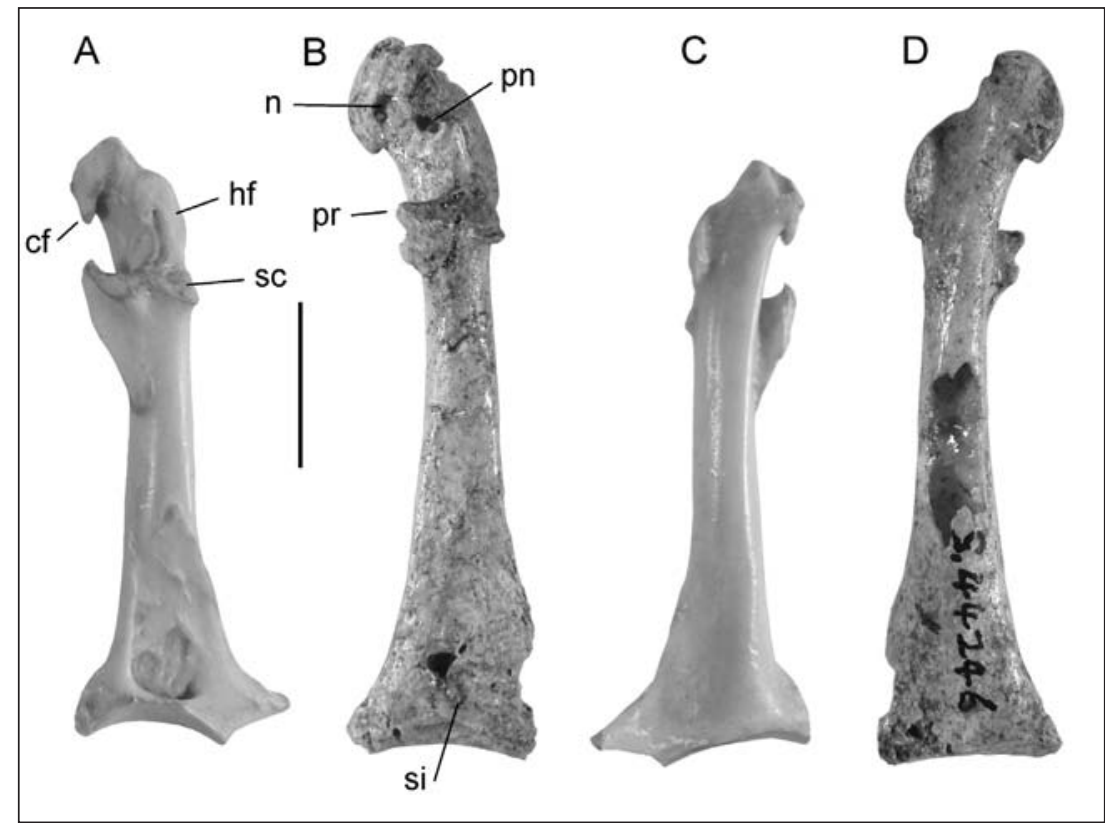

Figure 1. Right coracoids of Didunculus strigirostris AM S303 (A, C) and Bountyphaps obsoleta NMNZ S.44246 (B, D) in dorsal aspect (A, B) and ventral aspect (C, D). Scale bar is $10 \mathrm{~mm}$. Abbreviations: cf, clavicle facet; hf, humeral facet; n, notch; pn, pneumatic foramen; pr, procoracoid; sc, scapular cotyla; si, sternocoracoidal impression.

Table 2. Measurements of selected elements of Bountyphaps obsoleta compared with the formerly sympatric columbids Gallicolumba leonpascoi and Ducula harrisoni.

\begin{tabular}{llllll}
\hline Measurement & Coracoid ML & L scapula cotyla - tip acrocor & Hum PW ex dorsal tubercle & Tib DW & L cmc \\
\hline Bountyphaps obsoleta & 42.7 & 14.3 & 15.7 & $8.2,9.2$ & 33.8 \\
G. leonpascoi & 28.4 & - & $9.9-10.8$ & $7.5-7.8$ & $21.9-24.2$ \\
D. harrisoni & $41.6-42.2$ & $12.0-13.3$ & $16.5-17.6$ & $10.6-10.8$ & $39.1-39.6$ \\
\hline
\end{tabular}

Abbreviations: as in Methods, and acrocor, acrocoracoid.

is very similar in length to that of Didunculus (AM S.303) $33.7 \mathrm{~mm}$, and Columba vitiensis (AM 0.7921) $34.1 \mathrm{~mm}$, and so smaller than specimens referred to Ducula harrisoni (Table 2). The Henderson fossil has a less inflated trochlea carpalis than does Columba vitiensis, and a very shallow fossa infratrochlearis, shallower than in Didunculus Ducula and Columba. It is further distinguished from Didunculus by a lack of a fossa at the base of the os metacarpalis alulae on the dorsal facies and from Columba, Ducula and Didunculus by a stouter, less cranially directed extensor process.

Tibiotarsus. The specimens NMNZ S.44256 and S.44259 (Figure 2) allow determination of the arrangement of ligamental attachment points on the distal tibiotarsus in Bountyphaps obsoleta, which differ markedly between columbid taxa (Worthy 2001). 1. The tuberosity for the proximal attachment of the retinaculum extensorium tibiotarsi (ptRET) is prominent and is separated from the condylus medialis by a distance less than the height of the medial condyle (as in Goura, Microgoura, Natunaornis, Caloenas, Didunculus, Gallicolumba, Otidiphaps, Ocyphaps and Phaps), but differing markedly from Ducula, Columba, Hemiphaga and Ptilinopus where the ptRET is located farther proximally. 2. The distal attachment point for the retinaculum extensorium tibiotarsi (dtRET) is a marked prominence on the pons supratendineus (as in Didunculus, Gallicolumba, Ocyphaps, Phaps, Natunaornis, Goura, Microgoura, Caloenas), but is shifted proximally to merge into a ridge on the lateral side of the sulcus extensorius in Ducula, 


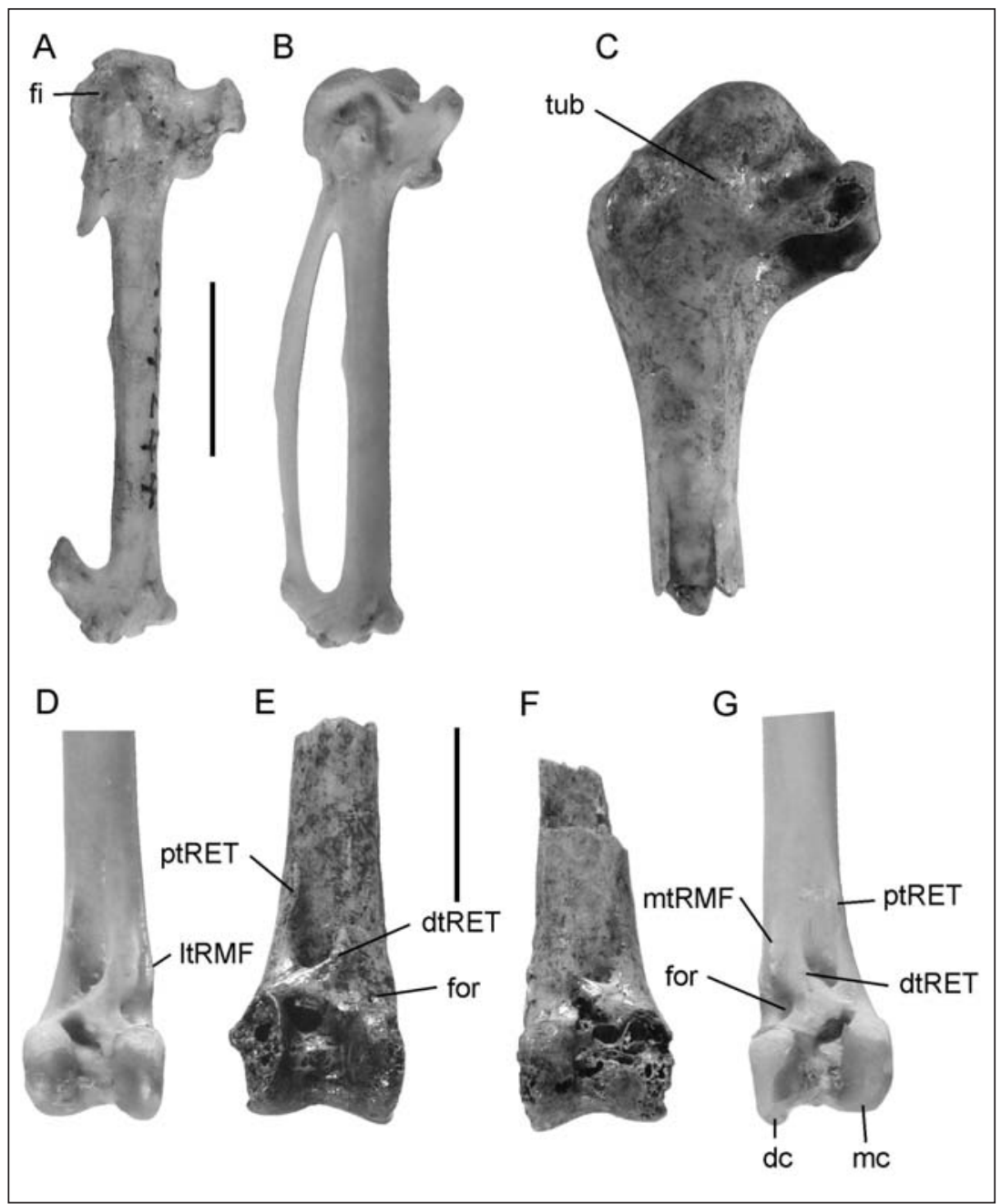

Figure 2. Carpometacarpi $(A, B)$ in ventral aspect, proximal left humerus in caudal aspect (C), and distal tibiotarsi in anterior aspect (D-G) of Bountyphaps obsoleta (A, NMNZ S.44244; C, S.44247; E, left, S.44259; F, right, S.44256) and Didunculus strigirostris AM S303 (B, D, H). B is a mirror image of the right element. Scale bar is $10 \mathrm{~mm}$. Abbreviations: $\mathrm{dc}$, dorsal condyle; dtRET, distal attachment retinaculum extensorium tibiotarsi; fi fossa infratrochlearis; for, foramen; ItRMF, lateral attachment retinaculum muscularis fibularis; mc, medial condyle; mtRMF, medial attachment retinaculum $m$. fibularis; ptRET, proximal attachment retinaculum extensorium tibiotarsi; tub tubercle.

Columba, Hemiphaga and Ptilinopus. 3. The lateral margin of the extensor sulcus proximal to the pons supratendineus is rounded (as in Goura, Microgoura, Caloenas, Didunculus, Gallicolumba, Ocyphaps and Phaps), so differing markedly from e.g. Natunaornis, Ducula, Columba, Hemiphaga and Ptilinopus, in which the sulcus has a sharp crest laterally. 4. There is no prominent medial attachment point for the retinaculum $m$. fibularis (mtRMF) laterad of the pons supratendineus, as in Natunaornis, Goura, Microgoura, Caloenas, Ducula, Columba and Ptilinopus. In contrast, Didunculus, Gallicolumba, Otidiphaps, Ocyphaps, and Phaps, have a prominent mtRMF attachment point. 5. The retinaculum $m$. fibularis (ltRMF) is positioned on the lateral facies and is aligned anterocaudally rather than parallel to the shaft, as in Natunaornis, Goura, Microgoura, Caloenas, Ocyphaps and Phaps. In Didunculus and Gallicolumba, the ltRMF is plainly visible in anterior aspect and is aligned parallel to the shaft. In Ducula, Columba, Hemiphaga, and Ptilinopus, the ltRMF is on the lateral facies and aligned parallel to the shaft. 6. A foramen penetrates the corpus at the anterior margin of the condylus lateralis distad of the mtRMF, as in 
Natunaornis, Goura, Caloenas, Ocyphaps, Phaps and Hemiphaga. A similar, but larger foramen is present in Microgoura, Didunculus and Gallicolumba. There is no such foramen in Ducula, Columba and Ptilinopus. 7. The width across the distal condyles is narrower posteriorly than anteriorly, as in Natunaornis, Goura, Microgoura, Caloenas, Didunculus, Gallicolumba, Ocyphaps, Otidiphaps and Phaps, rather than equal, as in Ducula, Columba, Hemiphaga and Ptilinopus. 8. The depth of the medial condyle is greater than the distal condylar width (as in Natunaornis, Goura, Microgoura, Caloenas, Didunculus, Gallicolumba, Otidiphaps, Ocyphaps and Phaps) but these values are about equal in Ducula, Columba, Hemiphaga and Ptilinopus. This feature can be otherwise expressed in terms of overall width and depth: in the former group of taxa the depth of the condyles is about equal to or deeper than condylar width, whereas in the latter group, condylar width is greater than their depth. The Henderson tibiotarsi thus differ markedly from Ducula, Columba, Hemiphaga and Ptilinopus. They are most similar to Goura, Microgoura, and Caloenas (share eight characters), then Natunaornis, Ocyphaps and Phaps (seven characters), but also have significant similarity with Didunculus and Gallicolumba (six characters). We interpret these similarities as homoplasy due to a terrestrial habit for all of these taxa. Measurements of distal width are less than those of Ducula harrisoni (Table 2).

\section{Discussion}

Wragg and Weisler (1994) and Wragg (1995a) recorded the presence of a distinct undescribed genus and species of pigeon on Henderson Island. Here we have described this taxon as Bountyphaps obsoleta based on 18 bones from four archaeological sites (1, 5, 6 and 11). Both sites five and six contained prehistoric material mixed into the archaeological sequence by the burrowing activities of sea birds, as evidenced by dates on bones up to $13,420{ }^{14} \mathrm{C}$ yrs $\mathrm{BP}$ (OxA-5910), with this oldest date being on bones of Gallicolumba leonpascoi (Hedges et al. 1997; Wragg 1995b). However, the deposition of most specimens was in Polynesian middens (Wragg 1995b). Polynesians occupied Henderson for about 600 years, commencing sometime in the period $1300-1000^{14} \mathrm{C}$ yrs BP, but certainly by about AD 1050 (Weisler 1995).

Bountyphaps obsoleta was the largest of the four columbids formerly extant on Henderson Island, and like Ducula harrisoni and Gallicolumba leonpascoi (Worthy and Wragg 2003; Wragg and Worthy 2006), it went extinct following the colonisation of Henderson Island by people. Only Ptilinopus survives today. The affinities of Bountyphaps obsoleta are obscure at present, and would be facilitated by the discovery of tarsometatarsi. Its relationships are currently perhaps partly confounded by homoplasy related to convergence to a terrestrial habit, but these initial comparisons suggest it is most closely related to Didunculus and Caloenas. Both taxa have relict distributions in the Pacific now with extinct taxa on widely separated islands (Steadman 2006a, b). In particular, Caloenas nicobarica has a modern distribution in New Guinea, the Bismarck Archipelago, Palau and the Solomon Islands (Steadman 2006a), but the fossil taxon C. canacorum (Balouet and Olson 1989) is found in New Caledonia and Tonga (Steadman 2006a).

The few available specimens indicate Bountyphaps obsoleta had relatively reduced wings for its body size, as indicated by its coracoid length compared with the sympatric Ducula. This suggests $B$. obsoleta was a comparatively weaker flier, but as the legs are not relatively larger than D. harrisoni, it probably was not flightless.

Steadman (2006a) detailed the distribution of extant and prehistoric columbids throughout the Pacific Ocean, finding them the most taxonomically diverse family of land birds in the region. He listed 10 described and four undescribed extinct taxa in seven genera. Bountyphaps obsoleta adds to this diversity and shows yet again how multiple pigeon genera coexisted on Pacific islands. The listing of Ducula aurorae and D. galeata in the former Henderson fauna 
(e.g. Steadman 2006a) is no longer tenable, as the bones these taxa were listed from together are Ducula harrisoni (Wragg and Worthy 2006). The description of B. obsoleta completes the description of the extinct Henderson Island columbids. In prehistoric times, this small island had four genera and species (B. obsoleta, Gallicolumba leonpascoi, Ducula harrisoni and Ptilinopus insularis), of which only the latter survives. Doubtless, as shown by the data in Steadman (2006a), further genera and species of pigeon will be described from Pacific fossil avifaunas. Large and unique forms certainly await discovery on islands impacted by humans for which palaeofaunas are so far lacking.

\section{Acknowledgements}

We are pleased to acknowledge Marshall Weisler, who led the archaeological investigations that were part of the Sir Peter Scott Commemorative Expedition to the Pitcairn Islands 1991-1992, and whose work thus is primarily responsible for recovery of the specimens described here. GW also thanks the people of Pitcairn for the hospitality given to him and other expedition members at that time.

This study was much advanced by the patient assistance of the curators and collections managers in the following institutions: AIM - Brian Gill; AM - Walter Boles; AMNH Paul Sweet, Allison Andors, Christine Blake; BMNH - Joanne Cooper for measurements of specimens; CM - Paul Scofield and for associated data; FM - Tarisi Sorovi-Vunidilo, Sagale Buadromo; LACM - Christina Couroux; NMNZ - Alan Tennyson, Sandy Bartle; MVZ Carla Cicero; USNM - Storrs Olson, Phil Angle; UWBM - Robert C. Faucett.

\section{References}

Balouet, J.C. and S.L. Olson 1987. An extinct species of giant pigeon (Columbidae: Ducula) from archaeological deposits on Wallis (Uvea) Island, South Pacific. Proceedings of the Biological Society of Washington 100(4):769-775.

Balouet J.C. and S.L. Olson 1989. Fossil birds from late Quaternary deposits in New Caledonia. Smithsonian Contributions to Zoology 469:1-38.

Baumel, J.J. and L.M. Witmer 1993. Osteologia. In J.J. Baumel, A.S. King, J.E. Breazile, H.E. Evans and J.C. Vanden Berge (eds), Handbook of avian anatomy: Nomina Anatomica Avium, Second Edition. Publications of the Nuttall Ornithological Club 23, pp. 45-132, figs 4.1-4.18.Cambridge: Massachusetts.

Bourne, W.R.P. and A.C.F. David. 1986. Henderson Island. Nature 322:302.

Fosberg, F.R., M.-H. Sachet and D.R. Stoddart 1983. Henderson Island (Southeastern Polynesia): Summary of current knowledge. Atoll Research Bulletin 272, 1-47.

Hedges, R.E.M., P. B. Pettitt, C.B. Ramsay and G.L. Van Klinken 1997. Radiocarbon dates from the Oxford AMS system: Archaeometry datelist 24. Archaeometry 39:445-471.

James, H.F. and S.L. Olson 1991. Descriptions of thirty-two new species of birds from the Hawaiian Islands: Part 2. Passeriformes. Ornithological Monographs 46:1-88.

Olson, S. L. and H.F. James 1991. Descriptions of thirty-two new species of birds from the Hawaiian Islands: Part 1. Non-Passeriformes. Ornithological Monographs 45:1-88.

Schubel, S.E. and D.W. Steadman 1989. More bird bones from archaeological sites on Henderson Island, Pitcairn Group, South Pacific. Atoll Research Bulletin 325:1-13.

Sinoto, Y. 1983. An analysis of Polynesian migrations based on the archaeological assessments. Journal de la Société des Océanistes 39:57-67. 
Spencer, T. and T.G.Benton 1995. The Sir Peter Scott Commemorative Expedition to the Pitcairn Islands 1991-1992. In T.G. Benton and T. Spencer (eds), The Pitcairn Islands: biogeography, ecology and prehistory, pp 1-5. London: Academic Press Ltd.

Steadman, D.W. 1989a. Extinction of birds in Eastern Polynesia: a review of the record, and comparisons with other Pacific Island groups. Journal of Archaeological Science 16:177-205.

Steadman, D.W. 1989b. New species and records of birds (Aves: Megapodiidae, Columbidae) from an archaeological site on Lifuka, Tonga. Proceedings of the Biological Society of Washington 102(3):537-552.

Steadman, D.W. 1992. New species of Gallicolumba and Macropygia (Aves: Columbidae). Los Angeles County Museum of Natural History, Science Series 36:329-348.

Steadman, D.W. 1993. Biogeography of Tongan birds before and after human impact. Proceedings of the National Academy of Sciences U.S.A. 90:818-822.

Steadman, D.W. 1994. Bird bones from the To'aga site, Ofu, American Samoa: prehistoric loss of seabirds and megapodes. University of California Archaeological Research Facility, Contributions 51:217-228.

Steadman, D.W. 1995. Prehistoric extinctions of Pacific island birds: Biodiversity meets zooarchaeology. Science 267:1123-1131.

Steadman, D.W. 1997. The historic biogeography and community ecology of Polynesian pigeons and doves. Journal of Biogeography 24:737-753.

Steadman, D.W. 2006a. Extinction and Biogeography of tropical Pacific birds. Chicago: University of Chicago Press.

Steadman, D.W. 2006b. An extinct species of tooth-billed pigeon (Didunculus) from the Kingdom of Tonga, and the concept of endemism in insular land birds. Journal of Zoology 268:233-241.

Steadman D.W. and S.L. Olson 1985. Bird remains from an archaeological site on Henderson Island, South Pacific: man-caused extinctions on an 'uninhabited' island. Proceedings of the National Academy of Sciences, USA 82:6191-6195.

Steadman, D.W. and B. Rolett 1996. A chronostratigraphic analysis of landbird extinction on Tahuata, Marquesas Islands. Journal of Archaeological Science 23:81-94.

Steadman, D.W., T.H. Worthy, A.J. Anderson and R. Water 2000. New species and records of birds from prehistoric sites on Niue, Southwest Pacific. Wilson Bulletin 112(2):165-186.

Weisler, M.I. 1994. The settlement of remote Polynesia: new evidence from Henderson Island. Journal of Field Archaeology 21:83-102.

Weisler, M.I. 1995. Henderson Island prehistory: colonisation and extinction on a remote Polynesian island. In T.G. Benton and T. Spencer (eds), The Pitcairn Islands: biogeography, ecology and prehistory, pp. 377-404. London: Academic Press Ltd.

Worthy, T.H. 2000. The fossil megapodes (Aves: Megapodiidae) of Fiji with descriptions of a new genus and two new species. Journal of the Royal Society of New Zealand 30:337-364.

Worthy, T.H. 2001. A giant flightless pigeon gen. et sp. nov. and a new species of Ducula (Aves: Columbidae), from Quaternary deposits in Fiji. Journal of the Royal Society of New Zealand 31:763-794.

Worthy, T.H. and G.M Wragg 2003. A new species of Gallicolumba: Columbidae from Henderson Island, Pitcairn Group. Journal of the Royal Society of New Zealand 33:769-793.

Wragg, G.M. 1995a. The fossil birds of Henderson Island, Pitcairn Group: natural turnover and human impact, a synopsis. In T.G. Benton, T. Spencer (eds), The Pitcairn Islands: biogeography, ecology band prehistory, pp. 405-414. London: Academic Press Ltd.

Wragg, G.M. 1995b. The fossil birds of Henderson Island, Pitcairn Group, South Pacific: a chronology of human-caused extinctions. Unpublished D.Phil, University of Oxford.

Wragg, G.M. and M.I. Weisler 1994. Extinctions and new records of birds from Henderson Island, Pitcairn Group, South Pacific Ocean. Notornis 41:61-70.

Wragg, G.M. and T.H. Worthy 2006. A new species of extinct imperial pigeon (Ducula: Columbidae) from Henderson Island, Pitcairn Group. Historical Biology 18(2):127-140. 